\title{
ARTICLES
}

\section{THE QUR'ĀNIC IDENTITY OF THE MUSLIM UMMAH: TAWHIDIC EPISTEMOLOGY AS ITS FOUNDATION AND SUSTAINER}

\author{
Osman Bakar*
}

\begin{abstract}
This article seeks to serve as the necessary background and foundation to another article by the author which is to appear in the upcoming issue of this journal. It explains the identity of the Muslim community (ummah) within the framework of the qur'ānic theory of multi-religious identities rooted in a common identity structure for all revealed religions and their respective communities. Tawhidic epistemology is central to the identity of the Muslim ummah. The essence of the ummah is a knowledge-community with its distinctive knowledge-culture founded on the qur'ānic tawhìd and the Muhammadan sharīah. Tawhidic vision of knowledge upholds the categorical position that all true human knowledge ought to be ultimately related to the unity of God, since all things are ontologically related to their Divine Origin. Muslims today no longer possess the whole of tawhidic epistemology along with its accompanying exemplary thinking culture. The eclipse of tawhidic epistemology has resulted in deviations in thinking modes from established norms rooted in traditional Islamic intellectual culture. Only a sound epistemological order exemplified in tawhidic epistemology may guarantee a healthy thinking and knowledge-culture on which alone the strength of the Muslim ummatic identity depends.
\end{abstract}

\section{The Scriptural Basis of a Common Identity Structure for Religious Communities}

There is a portion of a verse in the Qur'ān laden with ideas that may serve as guiding principles for a wide range of purposes related to the global pursuit of interreligious understanding and peace. The verse reads:

* Osman Bakar is the Deputy CEO of IAIS Malaysia and Emeritus Professor of Philosophy of Science at the University of Malaya, Kuala Lumpur. This article is a vastly expanded and revised version of a paper which he presented at the International Conference on 'Envisioning the Future of the Islamic World in the Era of Uncertainties: Views of Scholars' held at the Sultan Omar 'Ali Saifuddien Centre for Islamic Studies (SOASCIS), University of Brunei Darussalam, 15-17 September 2011. 
To each among you, We have prescribed a Law (shirah) and a spiritual Way (minhaj). If God had so willed, He would have made you a single people, but (His Plan is) to test you in what He had given you: so strive as in a race in all virtues. The goal of you all is to God; it is He that will show you the truth of the matters in which you dispute. ${ }^{1}$

Analysis of this verse allows us to establish its core ideas and the main purposes which they might serve. To begin with, the verse needs to be understood as being directed by God to the whole of the human family in order to explain the true meaning of the phenomenon of religious diversity and pluralism that has aroused so many controversies among both believers and disbelievers in God. As explained by Ibn 'Abbas, an uncle and companion of the Prophet Muhammad, who is generally regarded as the first commentator on the Qur'ān, the expression "to each among you" (li kullin ...minkum) in the verse denotes "to each prophet (nabiy) among you.". Muhammad Asad, a modern commentator, uses the equivalent expression "unto every one of you" to translate the Arabic phrase. ${ }^{3} \mathrm{He}$ interprets it as denoting "the various communities of which mankind is composed." The interpretations given by Ibn 'Abbās and Muhammad Asad are equivalent, since, according to the Qur'ān, God has sent apostles (sing: rasül) to every community (ummah). ${ }^{5}$ Accordingly, the expression "to each among you" conveys the idea that in human religious history, each Prophet ${ }^{6}$ and his religious community were recipients of "something" precious from God and this "something" is described in the words that immediately follow it: "We [i.e. God] have prescribed a Law and a spiritual Way (jacalnā ...shir $a t^{a n} w a$ minhaja)." From the point of view of the essential needs of every religious community, these are undoubtedly God's two most precious gifts.

This brings us to the second important idea in the verse, namely that, through His agency of prophethood and apostleship, God gave each community a shircah and a minhaj. Commentators generally understand the word shir $a h$, which occurs only once in the Qur'ān, to mean "the sacred law" that would be subject to developments, both approved and otherwise. When interpreters identify shir $a$ h as synonymous with $\operatorname{sharl}^{\mathrm{a}} a h$, it means that they have added to the revealed shir ah (law) the human interpretations of it as dictated or influenced by its developmental process, since the word $\operatorname{shart}^{\top} a h$ is traditionally understood to mean the combination of both the divinely given and the humanly interpreted laws. ${ }^{7}$ The word minhaj, however, is interpreted in a more varied way. Ibn 'Abbas interprets minhaj to mean farā' $i d$ wa sunan. ${ }^{8}$ Early Arabic lexicons explain minhaj as meaning "an open road" and "a clear path" and fara 'id and sunan as having a common meaning of a way or path (tariqah) of life that God has ordained on man and his community, which in the case of the People of the Book (sunnat ahl al-kitāb) may have undergone 'disapproved' developments. ${ }^{9}$ Yusuf 'Ali, on the basis of classical commentaries, interprets minhaj to mean "the finer things which are above the law, but which are yet available to everyone, like a sort 
of open highway." ${ }^{\prime 10}$ Similarly, Asad understands minhaj to mean "an open road" that is "usually abstract in nature."

On the basis of the above discussions of the word minhaj found in both early and modern qur'ānic commentaries as well as in classical Arabic lexicons, I argue that it would be best to translate it as "a spiritual way" to be understood as the inner dimension of religion as contrasted with law, which is viewed as its external societal dimension. To further strengthen this interpretation, making clearer the meaning of this inner dimension, let me advance two more arguments. First, there are qur'ānic verses that show that man has two fundamental needs, one arising from his "vertical" [i.e. metaphysical] relations with God and the other from his "horizontal" relations with the community. ${ }^{12}$ The first need refers to his beliefs, individual and collective, about God as the Absolute and Ultimate Reality that is the source of all other realities and his spiritual path to Him. The second need refers to the ethical-moral principles and injunctions that are to guide and regulate his conduct in every facet of his earthly life, both private and communal. These two needs refer to minhaj and shir ${ }^{c} a h$ respectively that are under discussion.

The second argument considers that man is naturally constituted in such a way that he exists both as a thinking and believing creature and as an acting creature. As the former kind of creature, his intellect-reason alone, with its thinking powers, does not suffice to help him fulfil his holistic needs. He needs a supra-rational guidance that provides him with the true knowledge of Reality [i.e. God] and spiritual practices that help deepen his relation with Him. This guidance would be best provided by a divine minhaj. As the latter kind of creature who has to live a communal life, he needs a practical code of conduct which in terms of comprehensiveness relative to its time and efficacy could only be provided by a divine shir $a h$. The above two arguments would also help to explain the perennial nature of the two divine gifts - minhaj and shircah - to all religious communities throughout human history. These gifts are meant to address man's perennial needs arising from his own natural constitution and the nature of Reality in which he occupies a central place and role.

The third important idea in the verse pertains to the identity of each religious community. The sentence that follows mention of the two gifts makes clear that it is not God's Plan to make humankind "a single religious community (ummat wăhidat ${ }^{a n}$ )," although He could have made it so if He wanted to. He made the religious communities different from each other by giving each of them a unique shir $a h$ and minhaj. In other words, the identity of each community is definable in terms of its unique shir 'ah and minhaj.

The fourth important idea conveyed by the verse concerns the purpose of this diversity. Three related purposes are mentioned in the rest of the verse. The first purpose is "to test you in what He [i.e. God] has given you." The second purpose is to inspire the different communities to "strive as in a race in all virtues." And the 
third purpose is to demonstrate to all communities that "the goal of you all is to God." Yusuf "Ali interprets the expression "to test you" (li-yabluwakum) to mean "to test our capacity for Unity (wahdaniyyah)."13 We may therefore view the three purposes together as emphasising the human need for unity in diversity in collective life within a pluralistic community as well as the human challenge to realisation. In stating the purposes of religious diversity, the Qur'ān seeks to underline the main principles governing interreligious understanding and peace in the global human community.

The four important ideas identified in the qur'ānic verse under consideration serve the extremely useful purpose, especially in the contemporary world, of providing a scriptural basis for the formulation of a universal theory of multiple identities for divinely revealed religions that are rooted in a common identity structure. The theory affirms that although all revealed religions have a common metaphysical origin, each of them has a unique identity resulting in the uniqueness of the community it founded as well. The structural elements shaping the identity of each religion and its ummah are its shir ah and minhaj. However, by virtue of their common metaphysical origin and their common identity structure, revealed religions and their communities are found to share common spiritual and ethical-moral teachings, as the science of comparative religion would readily testify. The idea of shared spiritual truths and values among the followers of the different religions is of great practical significance to interreligious peace.

It is within the framework of this theory that this article seeks to develop a detailed understanding of the identity of the community which the Prophet Muhammad founded on the teachings of the Qur'ān. The technical term in traditional Islamic scholarship for this community, the usage of which would be far more in conformity with the above theory of multiple religious identities than the modern usage of the term 'Muslim ummah', is ummat ${ }^{u n}$ Muhammad ${ }^{u n}$ ('Muhammadan community'). It was used widely by Ibn 'Abbās in his tafsir. The identity of the Muslim ummah thus understood will be used as the basis of discussion in the coming article to examine and prove the claim that the ummah is indeed passing through a worrisome identity crisis.

Some people may view the theory that revealed religions have distinct identities as contrary to the qur'ānic verse "verily, the religion before God is Islam." ${ }^{14}$ In response, I maintain that while it is true to say that the Qur'ann gives the same name to all His religions, namely Islam, as this verse clearly shows, nonetheless it also furnishes us with evidence that the dimensions of both law and creed vary in several respects from revelation to revelation. There is no contradiction between the two verses if the word 'al-Islam' in the second verse is understood correctly. As explained by Ibn "Abbās, "God bears witness that the religion (al-dīn) before Him is Islam, the earlier as well as the latter." ${ }^{15} \mathrm{He}$ further says that "the angels, the prophets, and the believers also bear witness to this [truth]." 
the word 'Islam' is to be understood in its universal sense as a generic name for the 'religion of submission' (din al-islam)." All prophets bear witness to this universal truth, as he has emphasised. ${ }^{17}$ 'Islam' thus refers to the religion of submission of each prophet and not just the religion revealed to the Prophet Muhammad.

However, the revealed forms and manners of submission vary from prophet to prophet. This variation in submission to God is to be observed in the different Laws $\left(\operatorname{shara\overline {a}} i^{c}\right)$ given to the prophets. In his explanation of the other verse, Ibn 'Abbās asserted that God could have made the whole of mankind a single community with "a single Law" (shart ${ }^{a} t^{a n}$ wăhidat ${ }^{a n}$ ), but instead He wanted to have a diversity of religious communities, each with its own shir'ah (or shart'ah). In other words, the Islam that was revealed to the Prophets is not one and the same. For example, we know too well that the Mosaic Law (shart'ah) is not the same as the Muhammadan shari ${ }^{\prime} a h .^{18}$ This is perfectly understandable, since a divine shari ${ }^{\circ} a h$ is meant to address both the permanent and changing needs of man, and the latter needs to vary with respect to time and space. Even at the level of beliefs, there is substantial variation in the doctrinal formulation and expressions of the principle of Divine Unity (altawhid), which is the core of each minhaj discussed earlier, as well as in its content. The Qur'ān maintains that God has sent apostles to every ummah ('community') ${ }^{19}$ to deliver His message in the language (lisān) of his own people. ${ }^{20}$ It is variations in the content and language of revelation ${ }^{21}$ and in man's 'logical' needs that explain variations in doctrinal formulations of tawhì.$^{22}$

These assertions show that even if the original religion ('the qur'ānic Islam') of each prophet has survived to this day without undergoing any changes, it would still be possible for us to speak of it as having an identity that distinguishes it from the other revealed religions. We know that all religions have undergone historical developments and changes, some more substantial than others. However, despite these developments and changes, including the significant deviations from their respective original doctrines of tawhi $\bar{d}$ and domains of sacred law, as observed in many religions - which the Qur'ān does not hesitate to criticise - the theory of multiple identities for revealed religions and their respectively generated communities still holds true. There is still the need to address the important issue of identity transformation that some religions have undergone as a result of their fundamental developmental changes. Generally speaking, the developmental aspects of a religion always raise the controversial issue of orthodoxy, which is, however, beyond the scope of this article.

When the developmental aspects of religions are taken into account, then the identity of each religious community may be defined in terms of its creed (theological beliefs) and spiritual-moral Law. Accordingly, the identity of the Muslim ummah henceforth referred to as ummatic identity - may be defined in terms of the qur'ānic tawhìd and the Muhammadan shari ${ }^{i} a h$. However, as is true of other religious communities, the Muslim ummatic identity has many defining elements, some of 
which are more fundamental than others. In the following discussion, the focus is on its most fundamental defining elements, particularly tawhidic epistemology, because it is these elements that have been eclipsed by the secondary defining elements. The defining elements mentioned above - qur'ānic tawhìd and Muḥammadan sharì ah may be further reduced to their respective core components.

\section{Defining the Identity of the Muslim Ummah: Its Core Elements}

The essence of qur'ānic tawhìd is the first article of faith, namely the belief in one God, which, metaphysically speaking, contains all the other articles of faith (arkān al-īmān). The belief in one God is embodied in the principle of divine unity (al-tawhid), which is also contained in the Muslim testimony of faith (shahädah), "There is no god but God." The Muhammadan sharī'ah is founded on the five pillars of Islam (arkān alisläm), the essence of which is the first pillar itself. The first pillar comprises the two testimonies of faith (shahädatayn) that one has to formally declare upon accepting Islam. The first testimony - the declaration "There is no god but God" just mentioned - affirms the truth of divine unity, while the second - the declaration "Muhammad is the apostle of God" - affirms the truth of the Muhammadan apostleship. Since the two testimonies are stipulated on the basis of the Prophetic traditions ${ }^{23}$ as a necessary and sufficient qualification for membership of the Muslim community (ummah), they may be interpreted as the most fundamental defining elements of the ummatic identity.

Furthermore, since the principle of divine unity as the first defining element pertains to the witnessing of the absolute truth and thus to the highest knowledge, which is in principle the container and generator of all human knowledge, ${ }^{24}$ and the principle of Muhammadan apostleship as the second defining element pertains to the witnessing of the most important cosmological and societal truths, it follows that the Muslim ummatic identity is knowledge-based and knowledge-oriented. ${ }^{25}$ We may then define the Muslim ummah as "a knowledge-community founded on the twin principles of divine unity and Muhammadan apostleship." It is possible to further reduce the Muhammadan apostleship to its essential core, namely Muhammad as the "role model" (uswat al-hasanah) as maintained in the Qur'ān. ${ }^{26}$ Muhammad is the best role model for both individuals and the ummah, because he is the perfect microcosm of both the cosmos and the ummah. He is the perfect man and, through his exemplary life (sunnah), he is the personal embodiment of the ummah in its ideal form and manifestations. The ummatic identity is therefore inseparable from the idea of the Muhammadan reality from which the Muhammadan role model springs. Accordingly, we may also define the Muslim ummah as "a knowledge-community founded on the twin principles of divine unity and Muhammadan reality or substance."

The above definition of the Muslim ummatic identity is presented in its most universal and inclusive form, since the defining elements are the most fundamental 
possible. The identity depicted is in its most universal form, because there is no other principle that transcends the principle of divine unity (tawhìd). It is also depicted in the most inclusive form, because in the perspective of the Qur'ân, the Muhammadan apostleship embraces all the dimensions of apostleship and prophetic roles and careers of his predecessors combined. From the point of view of temporal role, the Prophet Muhammad is considered the most perfect prophet and apostle. ${ }^{27}$ As such, the principle of Muhammadan apostleship is able to comprehend all religious perspectives in the history of human life and thought.

As argued by many classical Muslim thinkers, the tawhīd of the Prophet Muhammad stands out as the most comprehensive and the most perfect. ${ }^{28}$ They cited in particular the qur'annic verse on "the perfect religion revealed to the Prophet" ${ }^{29}$ and the verse on "the Seal of the Prophets" ${ }^{30}$ (khätam al-nabiyin) in support of the idea of completeness and perfection of both qur'ānic tawhid and the Muhammadan sharīah. This means that if the Muslim ummah is to be defined as "a knowledge-community founded on the qur'ānic tawhìd and the Muhammadan shart'ah," its identity would still be universal and inclusive in nature.

\section{Dimensions of the Muslim Ummatic Identity}

There are many other defining elements of the Muslim ummatic identity, but for the main purpose of this article, it is not necessary to go through all of them. I describe some of these elements as exclusive in nature or as minor in comparison with the elements already discussed. An example of these would be the prayer direction (qiblah) towards Mecca. The change of qiblah from Jerusalem to the Ka ${ }^{\mathrm{c}} \mathrm{bah}$ in Mecca, as mentioned in the Qur'ān, ${ }^{31}$ was justified first and foremost on the ground of the need for the new Muslim ummah to have a distinctive identity. ${ }^{32}$ The Qur'ān describes this new religious community as ummat ${ }^{a n}$ wasat $t^{a n},{ }^{33}$ meaning the "justly balanced community" or "the community of the middle path." This means that balance and moderation are a defining element of the new ummah's identity. Interestingly, the Qur'ān views the change of qiblah as a decision based on knowledge,$^{34}$ thus strengthening the thesis that the Muslim ummah is a knowledge-community with knowledge-laden identity characteristics.

Another example of secondary and exclusive defining elements of the ummatic identity is the two annual Muslim religious festivals - ${ }^{c} \bar{l} d$ al-Fitr and ${ }^{c} \bar{I} d$ al-Adh $\bar{a}-$ mentioned in the hadìths. According to the Prophet, every ummah has its own religious festivals. For his ummah, its festivals are the two mentioned. Notwithstanding the significance of the new qiblah and the two festivals to the Muslim ummatic identity, they are of little relevance to the understanding of the identity crisis that is sought to be analysed in this article. Rather, in arguing for the notion of the Muslim ummah as a knowledge-community, the major dimensions of its identity, particularly as displayed by the Prophet's exemplary community in Medina, will be discussed. 


\section{The Exemplary Knowledge-Community}

The Muslim ummah was created to be a knowledge-community that would serve as a model for the rest of mankind. The Qur'ān describes the ummah under the Prophet Muhammad's leadership as "the best ummah evolved for mankind," 35 because, first and foremost, it was a knowledge-community. The Prophet himself affirmed this claim with his statement that "the best of my ummah is of my generation" $\left(k_{h a y r}\right.$ " $u m m a t^{i} q a r n^{i}$ ). As a further justification of the claim, we may argue that the three essential attributes of the best ummah mentioned in the verse are all knowledgebased, namely commitment to enrichment of the common good ( $\left.a l-m a^{c} r \bar{u} f\right)$, zerotolerance of all that is bad and evil (al-munkar), and faith in God (tu'minūna bi 'lläh). ${ }^{36}$ The three key terms to be understood here in relation to knowledge are al-macrūf, al-munkar, and imān. Both etymologically and conceptually, the Arabic word $m a^{c} r \bar{u} f$ refers to that which is well-known and universally acknowledged to be good. It is acknowledged as such through knowledge. Similarly, something is identified as munkar through knowledge. As the ummah increasingly expanded and became more complex, what were categorised as $m a^{c} r \bar{u} f$ and munkar also increased in scope and variety. It was with the view of refining the meanings of these two categories of human acts for both ethical and legal considerations and classifying them into their various respective grades and types that scholars of the ummah developed Islamic jurisprudence ( ${ }^{c} i l m$ al-fiqh) into a major and sophisticated religious science. This scientific and progressive nature of Islamic jurisprudence clearly shows the knowledge-laden nature of the fundamental practical criteria of the exemplary ummah.

Likewise, faith in God is a knowledge-laden criterion of the best ummah. In the Islamic perspective, knowledge ( $\left.{ }^{c} \mathrm{ilm}\right)$ and faith (imān) are not two mutually exclusive domains, let alone in conflict with each other. True faith in God is the real foundation of knowledge as emphasised by the Qur'ān. ${ }^{37}$ Knowledge and faith have a dynamic interaction in which each reinforces the other. Faith based on understanding can generate new knowledge just as increase in knowledge can strengthen faith. The articles of faith in Islam are all statements about knowledge and, in fact, in the history of Islamic thought, they serve as epistemological ${ }^{38}$ principles in the various cosmological, natural, and social sciences.

Taken together, the three criteria of ummatic excellence represent the necessary forces for societal balance and equilibrium. They embody the principle of balance between faith and action and between knowledge and practice. All human societies, regardless of their religious or ideological persuasions, perform the task of promoting the common good $\left(m a^{c} r \bar{u} f\right)$ and preventing the common evil (munkar) to various degrees of commitment and efficacy. However, it is faith in God that gives ultimate meaning and quality to the first two criteria and helps to sustain them. As long as faith in God remains strong in a society, the efficacy of the two 
societal tasks is assured. Thus, for the first several centuries in the history of Islam, the Muhammadan ummah played the role of a model knowledge-community admirably.

According to the Prophet, two functional groups stand above the rest in terms of their influence and impact on the community. These are the men of knowledge ('ulam $\bar{a}$ ') and the rulers and administrators (umara '). The state of health of the community and its quality of life depend, most importantly on the ideas and actions of these two groups. They are therefore the ones most responsible for preserving and sustaining the ummatic identity. Since the 'culama $\bar{c}$ 'are primarily concerned with issues of knowledge and intellectual power and the umarā' with issues of political power and leadership, I will now discuss the dimensions of the ummatic identity that correspond to these respective roles and functions in the community. Accordingly, the dimension associated with the 'ulam $\bar{a}$ ' is the epistemological dimension and the one with the umara $\overline{ }$ ' is the leadership-followership dimension.

\section{The Epistemological Dimension: Tawhidic Epistemology as Sustainer of the Muslim Ummatic Identity}

The Muslim ummatic identity as a tawhidic knowledge-community finds a more concrete meaning and expression through Islam's very nature and structure as a religion and its pervasive concern with knowledge. The Qur'ān affirms that Islam is the religion of truth ( $\operatorname{lin}$ al-haqq), ${ }^{39}$ meaning that it is founded on the nature of things. The religion is thus structurally divided into the dimensions of beliefs and practices - the articles of faith and the pillars of Islam respectively - to cater to man's needs arising from his twofold division into thinking and willing components explained earlier. In principle, Islam's knowledge-community is born out of the association of individuals who accept these knowledge-based beliefs and practices. Islam communalises these beliefs and practices so that they serve as the foundations of a knowledge-driven community that would be free of conflicts between individual and collective interests. In this perspective, the Muslim ummatic identity may be defined in terms of its obligatory acceptance of the articles of faith and the pillars of Islam as specified by the Prophet himself.

As emphasised earlier, the Muslim ummatic identity is founded on the metaphysical-theological principle of divine unity, which is Islam's most fundamental epistemological principle. The main content of Islamic epistemology is derived from the application of this principle to all domains and branches of knowledge. The knowledge of Divine Unity ( ${ }^{c} i l m$ al-tawhìd), which is basically knowledge of Divine Names, Attributes, and Qualities, gives rise to the various epistemological principles and cosmological sciences, which in turn serve as the basis of the natural and social sciences and all other sciences. Essentially speaking, it is this tawhidic epistemology that helps to sustain the ummah's identity as a knowledge-community. 
Three of these derivative epistemological principles are treated in this discussion, because of their singular importance to the understanding of the ummah's contemporary knowledge-culture and its unhealthy condition. These are the idea of the unity of knowledge, the idea of order and harmony in the domain of knowledge, including the categorisation of knowledge into numerous types ${ }^{40}$ and the idea of a hierarchy of knowledge.

More specifically, the idea of the unity of knowledge is derived from the Divine Name, al-'Alim ('The Omniscient'). All forms and all branches of knowledge are harmoniously interrelated by virtue of the fact that all human knowledge ultimately comes from God, although man may acquire it through various ways and means. There could not be any conflict between any two branches or bodies of knowledge. Since this idea is fundamental to tawhidic epistemology, it was practically realised as part of a living knowledge-culture. Consequently, Islamic society was spared such epistemological conflicts as between the natural sciences and the social sciences or the humanities as happened in the modern West. C. P. Snow's reference to the West's "conflict of the two cultures" ${ }^{41}$ bears a close relationship with these epistemological conflicts. However, losing the sense of the unity of knowledge with the import of new ideas and new knowledge from foreign sources into the Muslim community, the contemporary Muslim mind experiences only disunity and conflict. A Muslim mindset deeply conscious of the unity of knowledge would have transformed real or apparent disunity and conflict in knowledge-claims into a clear unity.

Closely related to the idea of the unity of knowledge is the idea of the order and harmony in the domain of knowledge. When the human mind is faced with having to organise knowledge according to some system in the midst of seeming disarray, disorganisation and confusion in the knowledge-field, then the need for the idea of order and harmony is apparent. It presupposes categorisations of knowledge into well-defined types and forms. It is natural for the human mind to love seeing order and harmony in the domain of knowledge, since it has been structured to fulfil its intellectual, rational, logical, and mental needs in an orderly fashion. The human mind hates images of disorganised knowledge. It was with the view of realising order and harmony in the field of knowledge and thought and of catering to man's natural intellectual and rational needs that the classical Muslims developed a knowledgeculture in which definitions, classifications, and logical rigour feature prominently. ${ }^{42}$

The traditional Muslim organisation of knowledge into the various sciences ( $\left.{ }^{c} u l \bar{u} m\right)$, to which they contributed a significant number of new academic disciplines, was also meant to serve the same purposes. However, order and harmony in the domain of knowledge would not be possible without the role of the principle of tawhìd as the ordering and organising principle. For this reason, when this particular role of tawhi $\bar{d}$ no longer finds a rightful place in the minds of the learned, then confusion and disorder will prevail in its knowledge system. 
The third idea - the hierarchy of knowledge - another central teaching of tawhidic epistemology, may be viewed as a key component of the idea of order and harmony, since it is meant to establish order and justice in human knowledge. The various forms and branches of knowledge need to be hierarchically ordered in accordance with their respective epistemological values which differ from each other. The Qur'ān and the prophetic hadiths do not support the idea that all branches of knowledge are of uniform values. On the contrary, they affirm the hierarchy of knowledge.

The principle of Muhammadan apostleship, which is a statement about the reality of Muhammad and his relationship with God, is yet another source of Islam's epistemological principles. There is total agreement among Muslims that Muhammad is an embodiment of human perfection with all its implications for both man's personal and collective life, although Muslims differ in interpreting the meaning of his perfection. For the Sufis, the second testimony serves as the foundation of their conceptions of the Muhammadan Reality (al-Haqiqah al-Muhammadiyyah) and the Perfect Man (al-insān al-kāmil), which are extremely important to their spiritual life. ${ }^{43}$ This testimony is related to knowledge in many different ways through the objectification of Muhammad the apostle into principles of various kinds such as the cosmological, psychological, educational, political, social, and moral-ethical.

By objectification, I mean that Muhammad is not simply the name of a person whose extraordinary life and prophetic career profoundly changed the world, but also a set of objective principles, primarily epistemological, that both serve as the foundations of various dimensions of human life and thought and explain their meanings and possibilities. Each of these principles is laden with knowledge. The Prophet's numerous names and titles ${ }^{44}-201$ in all according to tradition - testify to the substantive knowledge content of the second testimony and its diversification in macrocosmic and human reality. Moreover, in societal terms, his full life illustrates in a clear manner the idea of a complete practical application of the principle of tawhìd to human community-building.

\section{The Leadership-Followership Dimension}

Central to the character of any community, especially a religious one, are leadershipfollowership relationships, not just in politics but all fields. In Islamic perspectives, both leadership and followership are knowledge-based issues. Prophetic leadership provides the perfect model for societies aspiring to be a knowledge-community. It was clearly knowledge-based. In fact, the core element in prophetic leadership was intellectual leadership, by which I mean leadership in wisdom, knowledge, and ideas. ${ }^{45}$ Tradition maintains that the Prophet was the most knowledgeable of creatures. In defining the quality of leadership of his successors - the postprophetic leadership - he places emphasis on their possession of knowledge and 
wisdom. He made this very clear in one of his sayings when he asserted that the most qualified to inherit the leadership of the Prophets are those noted for their knowledge and learning (al-culama $\left.\bar{a}^{\prime}\right){ }^{46}$ His immediate successors - the four Rightly-Guided Caliphs (al-khulafä' al-rāshidūn) - were generally acknowledged as the best among his followers to inherit the prophetic leadership by virtue of the depth of their knowledge and piety. ${ }^{47}$ They were true ${ }^{c} u l a m \bar{a}^{\prime}$ and God-fearing umarā'.

Even in the subsequent periods when the quality of leadership of the ummah continued to decline with the 'ulama ' and umara ' crystallising into two separate institutions that found themselves frequently at odds with each other, many scholars kept reminding the leaders of their times to emulate prophetic leadership in their governance and administration. In theory at least, as can be seen in the writings of Muslim political philosophers and jurists, intellectual or knowledgeleadership continued to be looked upon as a necessary and core component of political leadership. In practice, however, leaders who possessed within themselves both good knowledge and political leadership qualities were becoming rarer. When some scholars began to advance the idea of collective leadership to compensate for the loss of individual leaders endowed with many excellent attributes of prophetic leadership, the main hope then was that through this collective leadership the ummah's need for a sound intellectual leadership could be adequately met. ${ }^{48}$

In a knowledge-community as envisaged by Islam, its knowledge-based leadership is to be matched with a knowledge-based followership. Leadership and followership must go together according to well-defined relations. ${ }^{49} \mathrm{It}$ is meaningless to have good leaders without good followers, and vice versa. Within the framework of its tawhidic worldview, Islam has structured leadership-followership relations in its ummah in accordance with its social teachings and its earthly goal of societal salvation and ultimate goal of post-humus salvation. A knowledgeable and wellinformed followership presupposes the existence of a well-educated community, which Islam proposes to achieve through its philosophy of universal education.

It is such a community, of which the first generation of Muslims was the most exemplary, that would be in a position to put into the best practical shape the leadership-followership relations as envisaged by the Qur'ān and as exemplified by the Prophet and his companions. The most important principle defining these relations is the reciprocity between obedience and loyalty to leadership and the leadership's responsibility to look after the general welfare of the followers. Another principle is embodied in the idea emphasised in several hadiths, that "every person is both a leader and a follower, albeit in different contexts." If this idea is well understood and diligently put into practice in the various dimensions of a person's collective life, then it would go a long way towards bringing leadershipfollowership relations closer to the ideals set forth by Islam. 


\section{An Appropriate Thinking Culture for the Exemplary Ummah}

Thinking is central to human life. This fact and Islam's self-portrayal as a religion of knowledge explain its emphasis on healthy and correct thinking, especially on issues that really matter to human identity, worth, and dignity. Tawhidic epistemology provides indispensable guidelines to man for his proper appreciation of the place, role and function of $a l^{c} a q l$ ('intellect-reason'), which is his most important cognitive instrument in the pursuit of knowledge, especially in relation to divine revelation, to ensure correctness in his thinking activities.

Islam views thinking as a defining element of human identity and by extension, ummatic identity. To be human is to be able to think, for which function God has endowed man with the cognitive faculty of intellect-reason $\left(a l^{-c} a q l\right) .{ }^{50}$ Traditional Muslim philosophers affirm this essential attribute of man by defining him as a rational animal (al-hayawān al-nătiq).$^{51}$ The general objective of human reason is to know truths through correct thinking, thus to acquire knowledge. However, reason is susceptible to erroneous thinking. An error can be minor or major. What interest us here are errors that contradict the Qur'ān and established wisdom (al-hikmah). Moreover, these errors may be collective in being committed by a whole community or society. The collectivity committing the error may not admit that they have done so. On the contrary, they may claim that they are right! However, by virtue of its position as a divinely revealed criterion of truth and error, the Qur'ān often makes judgments that 'collective errors' have indeed been committed.

When the collectivity happens to be a whole civilisation or the greater part of it, the 'collective error' becomes elevated to a 'civilisational error'. In the history of Western thought, civilisational errors of various magnitudes have been committed. For example, the birth of the modern secular West was partly founded on a major error, namely the belief that the collective human mind has no need of divine revelation to guide it in the pursuit of knowledge and meaningful life and civilisation-building. This collective error became a civilisational one when it was adopted as one of the foundational pillars of modern Western civilisation.

Islam takes very seriously such collective errors. In its opening chapter (Sürah al-Fätihah), the Qur'ān teaches mankind to pray to God to guide them to the straight path (al-sirät al-mustaqim).$^{52}$ There, the straight path is characterised as the path of "those who do not go astray." ${ }^{\circ 3}$ In another part of the Qur'ān, the straight path is defined as the worship of God the One alone..$^{54}$ In other words, the straight path is the path of tawhid. Given the centrality of thinking in human identity, correct or orthodox thinking must form an integral component of the straight path. In other words, to be on the straight path in one's life also means to lead a right way of thinking. In affirming orthodoxy in thinking, in which intellect-reason and revelation find a well-ordered and harmonious relationship, Islam at the same time cautions against heterodoxy in thinking. To follow a way of thinking and a way of knowledge that are totally 
independent of divine revelation would thus be a glaring deviation from the straight path of tawhìd. A collective mind immersed in such a deviationist thinking culture is viewed in the Islamic perspectives as having committed heterodoxy in thinking.

Since it is a major concern of Islam to at the same time promote and preserve orthodox thinking and prevent collective errors in man's thinking activities, its knowledge-culture has developed the finest logical tradition ever found in the history of human thought. I am referring to Islam's art of thinking as developed in the branch of knowledge known as 'ilm al-mantiq ('science of logic'). It should be noted that, in Islamic intellectual tradition, logic is not viewed merely as a part of a corpus of thinking tools $(\bar{a} l \bar{a} t)$. As a tool, logic can serve both truth and error. Islamic logic, however, is also concerned with the issue of the truth of premises needed for thinking processes. ${ }^{55}$ It is in this particular area of logical concern that there is a place for revealed data to serve as true premises. The traditional Islamic art of logic was sophisticated enough to be able to serve the logical and thinking needs of the Muslim minds without their having to revolt against God and His revelations or to abandon orthodoxy.

\section{Conclusion and Recommendations: The Restoration of Tawhidic Epistemology}

In my coming article, I will argue that the traditional Muslim ummatic identity that I have described, founded on and nourished and sustained by Islam's tawhidic espitemology, has been partially lost due to the disappearance of the best parts of this epistemology from the collective mind of the contemporary ummah. I will further argue that as a result of this loss, Islam's knowledge and thinking-culture have also been adversely affected, resulting in the contemporary ummatic identity crisis. I will propose concrete suggestions as to how to overcome this crisis in the ummah's knowledge and thinking-culture and educational systems.

On the basis of the whole foregoing discussion, I would like to suggest the following:

- Centres of Islamic studies need to intensify research on issues of ummatic identity given its importance to the health and dignity of the ummah;

- There should be more teaching and research programs on epistemology from the Islamic perspectives in the Muslim world that will result in much needed publications on the subject;

- Leadership-followership issues and the issue of the unity of the 'ulamā' and umara ' need to be further articulated for the benefit of the general public;

- Islam's knowledge and thinking-culture needs to be better understood and cultivated by the Muslims with the view of strengthening the ummatic identity. 


\section{Notes}

1. Qur'ān 5:48. Translations are from 'Abdullah Yusuf 'Ali, The Meaning of the Holy Qur'an: Text, Translation and Commentary (Kuala Lumpur: Islamic Book Trust, 2009), except indicated otherwise whenever I have to offer my own interpretations. For ${ }^{\mathrm{c}}$ Ali's discussion of this verse, see p. 219.

2. See Abū Țāhir Muhammad b. Ya ${ }^{c} q u \bar{b}$ al-Fīrūzābādī, Tanwīr al-maqbas min tafsīr Ibn ${ }^{c} A b b a \bar{s}$ (Cairo: Al-Halabi and Sons, 1370 AH/1951 CE), 76. Henceforth, this author will be cited as al-Fīrūzābādī and the work as Tafsīr Ibn ${ }^{c} A b b \bar{a} s$.

3. See Muhammad Asad (transl., explan.), The Message of the Qur'an (Gibraltar: Dar Al-Andalus, 1980), 153.

4. Ibid.

5. Qur'ān 10:47.

6. According to Islamic tradition, there were altogether 124,000 prophets from Adam, the first man and also the first Prophet, to Muhammad, the last of them.

7. See E. W. Lane, Arabic-English Lexicon (Cambridge: The Islamic Texts Society, 1984 edition), $2: 1535$.

8. al-Fīrūzābādī, Tafsìr Ibn 'Abbās, 76. Report by Nur Atifi, "COP15: The Good, the Bad and the Ugly," Business Today (Kuala Lumpur), 13 February 2010, 42.

9. Lane, Arabic-English Lexicon, 1:1438-39; 2:2374-75.

10. $\quad$ Ali, The Meaning, 219.

11. Asad, The Message, 153 .

12. Qur'ān 3:112. Part of this verse refers to the idea in question "hablin min Allah wa hablin min al-nas," which Asad translates as "a bond with God and a bond with men." In his note to this translation (note 83), Asad comments that the people of the Book who no longer observed "bond with God and with men" would be free of shame "if they return to the concept of God as the Lord and Sustainer of all mankind." Asad, The Message of the Qur'an, p. 84.

13. 'Ali, The Meaning, 219.

14. Qur'ān 3:19.

15. al-Fīrūzābādī, Tafsìr Ibn ${ }^{c} A b b a \bar{s}, 36$.

16. Ibid.

17. Ibn "Abbas paraphrased the statement "inna al-din cind Allah al-Islam" as "the most pleasing thing (al-mardiy) to God is submission to Him." Bin Ya'qub al-Firuzabadi, Tafsir Ibn cAbbas, p. 36.

18. I am using the word 'Muhammadan' in the traditional Islamic sense of a principle, as Ibn 'Abbas has done in his tafsir, that is applicable to and descriptive of such entities and realities as ummah, shart ${ }^{c} a h$, and the spiritual substance of the Prophet Muhammad to which the Sufis refer to as the Muhammadan Reality (al-Haqiqqah al-Muhammadiyyah) and the Muhammadan Light (al-Nür alMuhammadi). This Islamic usage long predated the Orientalists' usage of the word. The idea of the Muhammadan principle will be discussed in the later sections of this article.

19. Qur'ān 10:47.

20. Ibid., 14:4.

21. The word 'language' in the verse is to be understood not only in the ordinary sense as when we are referring to ethnic-based languages such as Arabic, Malay, Persian and so on, but also in the wider, supra-ethnic sense. In this wider sense, we are speaking of such types of language as the mythical and the symbolical. As cAli has commented on the verse: "There is even a wider meaning for 'language'. It is not merely a question of alphabets, letters, or words. Each age or people - or world in a psychological sense - casts its thoughts in a certain mould or form. Allah's message - being universal - can be expressed in all moulds and forms, and is equally valid and necessary for all grades of humanity [...];" see 'Ali, The Meaning, 494. 
22. A classical Muslim thinker who dealt with this issue in a detailed way was Ibn al- ${ }^{\mathrm{c}} \mathrm{Arab}$ (d. 1240). For his work on the role of various prophets in revelation and the dimension of divine Wisdom each represents, see Ibn al-'Arabī, Fușūṣ al-hikam (The Bezels of Wisdom), trans. and intro. R. W. J. Austin (New York: Paulist Press, 1980).

23. According to several hadìths narrated by 'Umar b. al-Khaț̣āb, the second caliph, it was the Prophet himself who identified the first pillar of Islam with the two testimonies of faith in response to the question "what is Islam?" posed by the Archangel Gabriel to him during a question and answer session on the meaning of religion (al-din $)$ which he and several of his companions had with the latter.

24. For a discussion of the role of the principle of divine unity contained in the first shahädah as the metaphysical container and generator of all knowledge, see Osman Bakar, Tawhid and Science: Islamic Perspectives on Religion and Science (Shah Alam [Malaysia]: Arah Publications, 2008, $2^{\text {nd }}$ ed.), especially the Introduction, Chapter 1, and Chapter 4.

25. From the point of view of the core concern of this article with the identity of the Muslim ummah, it is an extremely significant point to be noted that Islam defines the qualification of membership of the ummah in terms of knowledge.

26. Qur'an, Chapter 33 ("The Confederates"), verse 21.

27. In his commentary on the Muhammadan wisdom, Ibn al-'Arabī writes: "[ $\ldots]$ he is the most perfect creation of this humankind, for which reason the whole affair [of creation] begins and ends with him [...]. [H]e is, by his elemental makeup, the Seal of the Prophets." He goes on to say: "He was the clearest of evidence for his Lord, having been given the totality of the divine words, which are those things named by Adam" Fuṣuṣs al-hikam (The Bezels of Wisdom), trans. and intro. R. W. J. Austin (Ramsey, NJ: Paulist Press, 1980), 272.

28. For an excellent study of the treatment of this theme by classical Muslim scholars, see Annemarie Schimmel, And Muhammad is His Messenger: the Veneration of the Prophet in Islamic Piety (Kuala Lumpur: Islamic Book Trust, 2008), particularly Chapter 7.

29. Qur'ān 5:3.

30. Ibid., 33:40.

31. Ibid., 2:142-145.

32. For this and other justifications of the change, see 'Ali, The Meaning, 53-56.

33. Qur'ān 2:143.

34. In responding to the disputes about the qiblah change among the People of the Book, the Qur'ān (2:145) says: "[...] If you [i.e. the Muslims] were to follow their desires after the knowledge has reached you, then you were indeed in the wrong."

35. Qur'ān 3:110.

36. Al-Fārābī's Al-Madīnat al-fădilah (The Virtuous City) may be viewed as a philosophical commentary on the three criteria of ummatic excellence; see Abū Nașr al-Fārābī (trans. Richard Walzer), Al-Farabi on the Perfect State: Abū Nașr al-Fārābì's Mabādi' ārā' ahl al-madīna alfädila: A Revised Text with Introduction, Translation, and Commentary (Oxford: Clarendon Press, 1985), 245-249 (henceforth cited as al-Fārābī, The Perfect State, trans. Walzer).

37. The Qur'ān 2:26 says: "[...] Those who believe know that it is truth from their Lord."

38. I understand 'epistemology' to mean a theory or science of knowledge. Equivalently, I have defined it as 'vision of knowledge' on the understanding that 'vision' is what the Greek word theoria, from which the English word 'theory' is derived, actually means.

39. Qur'ān 61:9.

40. For a detailed discussion of these and other epistemological principles and categorisations of knowledge, see Osman Bakar, Classification of Knowledge in Islam (Kuala Lumpur: ISTAC, 2006).

41. See C. P. Snow, The Two Cultures (Cambridge: Cambridge University Press, 1993). Snow was 
referring to the long conflict between the arts or humanities on one hand and the sciences on the other.

42. For a detailed discussion of these various aspects of Islamic knowledge-culture see Bakar, Classification.

43. For a detailed discussion of these concepts as understood by various generations of Muslim scholars and thinkers see Schimmel, And Muhammad, Chapter 7 on "The Light of Muhammad."

44. See ibid., Chapter 6, which is wholly devoted to a discussion of the Prophet's names.

45. For a detailed discussion in early Islamic history of the eminent place of intellectual leadership quality in prophetic leadership from the perspective of political philosophy, see al-Fārābī, The Perfect State, trans. Walzer.

46. This is made clear in a hadith which asserts that "The men of knowledge (al-culama') are the inheritors of the Prophets."

47. According to al-Fārābī, the Prophet's immediate successors were distinguished by six qualities, all of which pertain to knowledge possession and excellent intellectual and rational virtues; see al-Fārābī, The Perfect State, trans. Walzer, 251-253.

48. For al-Fārābī's arguments for the justification of collective leadership and his insistence on the necessity of wisdom in any good leadership or government (al-hikmah juz' al-ri'āsah); see alFārābī, The Perfect State, trans. Walzer, 253.

49. For a discussion of this theme from the Islamic perspective see Osman Bakar, "Islamic Leadership in the Changing ASEAN: Fostering Peace and Development," in: Proceedings of Conference on Islamic Leadership in the Changing ASEAN (Manila: Asian Institute of Management, 2010), 38-55.

50. The word $a l^{c} a q l$ does not exist in the Qur'ān but its activities are frequently mentioned there through its related verb forms such as yac qilūn, tac qilün, and yatafakkarün. In the hadīths, however, the word $a l^{c} a q l$ is mentioned many times.

51. The Arabic words ${ }^{c} a q l$ and $n \bar{a} t i q$ have meanings that are related to intelligence. The word al-nătiq is etymologically related to al-nutq which has been related both to intelligence as acquired by man's rational faculty and man's intelligent speech. For this discussion, see Osman Bakar, "Islam and the Problem of Cultural Symbiosis," Al-Shajarah [Kuala Lumpur] 13, no. 1 (2008), 8-9.

52. Qur'ān, Chapter 1 ("The Opening"), verse 6.

53. Ibid., verse 7 .

54. The Qur'ān, 36:61, says: "And that you should worship Me; this is the straight path."

55. For a discussion of this issue see Bakar, Classification, 57-59. 